\title{
11 \\ IMPACT OF APPLYING SALINITY LEVELS AND SPECIFIC ANION OF IRRIGATION WATER ON SOME CHARACTERISTICS OF A CALCAREOUS SOIL CULTIVATED WITH BARLEY PLANTS
}

\author{
Nagat G.M. Aziz, Anas A.A. Wahdan and Ahmed A.A. Hassanien
}

Soils and Water Depart., Fac. of Agric., Cairo University, Fayoum Branch, Egypt.

\begin{abstract}
:
A green house pot experiment was conducted on a newly reclaimed clay loam calcareous soil at the eastern edge of Tamia district, El Fayoum Governorate. It was cultivated with barley (Hordeum vulgare, Giza 123) and irrigated with water of different salinity levels, i.e., 750, 1500,3000 and $4500 \mathrm{mg} / \mathrm{L}$, prepared from $\mathrm{NaCl}, \mathrm{Na}_{2} \mathrm{CO}_{3}$ and $\mathrm{Na}_{2} \mathrm{SO}_{4}$ salts. The current study aimed at identifying the response of both soil and grown barley characteristics to the total salt concentration as well as specific anion effects.

The obtained results showed pronounced increases in the values of bulk density and soil strength vs decreases in soil total porosity, hydraulic conductivity and available water range with increasing irrigation water salinity levels. Also, the negative effect depends upon salinity level and specific anion, however, both $\mathrm{NaCl}$ and $\mathrm{Na}_{2} \mathrm{SO}_{4}$ salts exhibited slightly hazardous effect vs an extremely one for $\mathrm{Na}_{2} \mathrm{CO}_{3}$, may be due the formation of false soil aggregates in the first case and the destroyer effect in the later one. The hazardous effect of the accompanied anions was arranged as follows: $\mathrm{CO}_{3}{ }^{2-}>\mathrm{Cl}^{-}>\mathrm{SO}_{4}{ }^{2-}$. In general, increasing applied water salinity levels resulted also in an increase for each of soil $\mathrm{pH}$ and ESP vs decreases in the released available nutrients for grown plants.

Results indicated that the hazardous effect of applied $\mathrm{NaCO}_{3}$ solution was extended to the grown barley characteristics. Barley vegetative growth parameters (plant height, No. of tillers/plant, No. of leaves/plant, leaf area/plant and leaves dry weight/plant) showed gradual decreases with increasing water salinity levels. Also, it is evident that the relatively high soil salinity leads to an uptake inhibition of plant roots for all nutrients, due to the inability of subcellular osmotic units to adjust the relatively high osmotic pressure and ionic strength.

Similar trends were noticed for barley yield (straw and grains) and its components (No. of grains/spike, 1000 grain weight, protein content $\%$ and nutrients uptake by plant). It is noteworthy to mention that reductions in yield resulted from the decreases in the number of grains per spike rather than the decrease in 1000 grain weight, which seems to be almost stable against the change of the unfavourable conditions of irrigation water salinity levels. Also, the reductions in straw yield, which amounted about 24-39\% at the highest water salinity level, were a function of the decrease in plant height in a minor magnitude due to tillering capacity of relatively major magnitude.
\end{abstract}

Key words: Barley, Saline waters, Calcareous soils, Specific anions effect, Macro and Micronutrients.

Fayoum J. Agric. Res. \& Dev., Vol.19, No.2, July, 2005 


\section{INTRODUCTION}

The majority of soils in arid and semi arid regions are sandy or calcareous in nature, having poor hydrophysical or fertility status and suffering from a shortage in fresh irrigation water resources. The use of saline water in agricultural purposes in Egypt started after 1950, since the shortage in resources of available good water for the newly reclaimed and cultivated land (Gupta, 1990).

Crop production using saline waters depends upon the tolerance of the crop, soil management and agro-climatic conditions. However, the use of saline water in irrigation causes negative effects on many of soil properties, i.e., $\mathrm{pH}$ and ion exchange equilibrium and salt concentrations (Wilcox and Durrum, 1967). El Gala et al. (1989), Ahmed et al. (1998), Megahed and Gaafer (2003) and El Tapey et al. (2005) confirmed negative effects of saline water as a source for irrigating barley grown on calcareous soils. They found pronounced decreases in the dry matter yields of straw and grains, protein content and nutrients uptake by barley plants as a result of increasing water salinity levels. They added that these parameters can be improved by applying some soil amendments, i.e., sulfur and farmyard manure. Megahed and Gaafer (2003) found that barley production could be improved by introducing high yielding varieties that show high adaptability to salinity stress conditions of water or soil.

Bayoumi et al. (1997) mentioned that $\mathrm{K}$ and $\mathrm{Zn}$ concentrations and uptake by barley decreases with increasing salinity level than $600 \mathrm{mg} / \mathrm{L}$ in irrigation water. El Tapey and Hassan (2002) found a specific effect for $\mathrm{SO}_{4}{ }^{2-}$ on decreasing soil $\mathrm{pH}$, enhancing the availability of $\mathrm{Zn}$ and consequently its uptake by plants under salinity stress. Abdel Aziz (2004) mentioned that the greater levels of salts in irrigation water more than $5.58 \mathrm{dS} / \mathrm{m}$ significantly decreased the dry matter yield of barley plants, while $\mathrm{Mn}$ and $\mathrm{Zn}$ concentrations in shoots and grains increased. El Tapey et al. (2005) found that vegetative growth parameters, yield and its components showed gradual significant decreases with increasing salinity levels in irrigation water. They added that $\mathrm{N}, \mathrm{P}, \mathrm{K}, \mathrm{Fe}, \mathrm{Mn}, \mathrm{Zn}$ and $\mathrm{Cu}$ contents in barley straw and grains were decreased with the progressive levels of salts in irrigation water used.

The present study is an attempt to assess the adverse effects of different irrigation water salinity levels on both soil and grown barley characteristics, with special reference to the influence of total salt concentrations and specific anion effect.

\section{MATERIALS AND METHODS:}

A green house pot experiment was conducted on a soil surface sample $(0-35 \mathrm{~cm})$ taken from a newly reclaimed calcareous soil at the eastern edge of Tamia district, El Fayoum Governorate. Soil was analyzed for physical and chemical properties according to Jackson (1973) and Page et al. (1982). Some properties of the experimental soil are shown in Table (1).

Fayoum J. Agric. Res. \& Dev., Vol.19, No.2, July, 2005 
IMPACT OF APPLYING SALINITY LEVELS AND SPECIFIC

Table (1): Some characteristics of the studied soil.

\begin{tabular}{|c|c|c|c|}
\hline Soil characteristics & Values & Soil characteristics & Values \\
\hline \multicolumn{2}{|l|}{ Particle size distribution \%: } & \multicolumn{2}{|l|}{ Soil chemical properties: } \\
\hline Coarse sand & 9.32 & $\overline{\mathrm{pH}}(1: 2.5$, ,soil suspension $)$ & 7.85 \\
\hline Fine sand & 16.75 & Organic matter $\%$ & 0.76 \\
\hline Silt & 38.10 & ESP & 9.17 \\
\hline Clay & 35.83 & $\mathrm{ECe}_{\mathrm{e}}$ in $\mathrm{dS} / \mathrm{m}$ (soil paste ) & 4.93 \\
\hline Textural class & CL & Soluble cations (me/) & \\
\hline Total calcium carbonate $\%$ & 38.74 & $\mathrm{Ca}^{2+}$ & 20.45 \\
\hline \multicolumn{2}{|c|}{$\mathrm{CaCO}_{3}$ distribution in mechanical fractions: } & $\mathrm{Mg}^{2+}$ & 9.65 \\
\hline$\overline{\text { Coarse sand }}$ & 0.95 & $\mathrm{Na}^{+}$ & 18.03 \\
\hline Fine sand & 4.76 & $\mathrm{~K}^{+}$ & 0.72 \\
\hline Silt & 7.55 & Soluble anions (me/l) & \\
\hline Clay & 25.48 & $\mathrm{HCO}_{3}^{-}$ & 2.80 \\
\hline Active $\mathrm{CaCO}_{3} \%$ of soil weight & 29.54 & $\mathrm{CO}_{3}{ }^{2-}$ & 0.00 \\
\hline \multicolumn{2}{|l|}{ Soil physical properties: } & $\mathrm{Cl}^{-}$ & 26.29 \\
\hline Soil strength $\left(\mathrm{kg} / \mathrm{m}^{2}\right)$ & 3.65 & $\mathrm{SO}_{4}^{2-}$ & 19.76 \\
\hline Bulk density $\left(\mathrm{g} / \mathrm{cm}^{3}\right)$ & 1.19 & \multicolumn{2}{|c|}{ Available nutrients (mg/kg soil): } \\
\hline Total porosity \%: & & $\mathrm{N}$ & 37.80 \\
\hline on volume basis & 51.43 & $\mathrm{P}$ & 5.38 \\
\hline on weight basis & 43.15 & $\mathrm{~K}$ & 301.5 \\
\hline Hydraulic conductivity $(\mathrm{cm} / \mathrm{h})$ & 1.38 & $\mathrm{Fe}$ & 6.21 \\
\hline Field capacity $\%$ & 33.90 & $\mathrm{Mn}$ & 2.53 \\
\hline Wilting point $\%$ & 14.73 & $\mathrm{Zn}$ & 1.46 \\
\hline Available water $\%$ & 19.17 & $\mathrm{Cu}$ & 1.21 \\
\hline
\end{tabular}

Plastic pots of $45 \mathrm{~cm}$ diameter and $35 \mathrm{~cm}$ height, with bottom gravel layers and holes to remove the excess of irrigation water, were used. Eight kg portions of air-dried soil were weighed in each pot, well mixed and packed in pots at the initial soil bulk density value of $1.21 \mathrm{~g} / \mathrm{cm}^{3}$. Twelve barley seeds were planted, and one week later they were thinned to 8 healthy seedlings. The pots were planted with barley (Hordeum vulgare, Giza 123) during the agricultural growing season of 2004/2005 and irrigated with the different irrigation water salinity levels of 750, 1500, 3000 and $4500 \mathrm{mg} / \mathrm{L}$. Each salinity level was prepared from $\mathrm{NaCl}, \mathrm{Na}_{2} \mathrm{CO}_{3}$ and $\mathrm{Na}_{2} \mathrm{SO}_{4}$ salts. The experiment was laid out with four treatments of the previous irrigation water salinity levels, with three replicates, and arranged in a complete randomized block design. The grown plants were fertilized with ammonium nitrate $(33.5 \% \mathrm{~N})$ at the rate of $60 \mathrm{~kg} \mathrm{~N} / \mathrm{fed}$ added in three equal doses (at 15, 30 and 60 days from planting). Superphosphate $\left(15.5 \% \quad \mathrm{P}_{2} \mathrm{O}_{5}\right)$ was added at the rate of $31 \mathrm{~kg} / \mathrm{fed}$ before planting. Potassium sulfate $\left(48 \% \mathrm{~K}_{2} \mathrm{O}\right)$ was applied at the rate of 48 $\mathrm{kg} / \mathrm{fed}$ added in three equal doses at the same dates of $\mathrm{N}$ application.

Samples of soils and barley plants were collected from each pot at elongation stage (after 80 days from planting and just before flowering) for determining the changes occurred in soil hydrophysical, chemical and fertility properties. The collected soil samples that taken were analyzed for bulk density (Black and Hartge, 1986), hydraulic conductivity, total porosity (Black, 1965). Soil strength and penetrability was estimated using the penetrometer (EISELKAMP-Giesbeek, Equipment, Netherland, Model 2-81154-2), which described by Klute (1986). Active calcium carbonate content (Yallon, 1957), soil moisture content at available range (Klute, 1986), soil

Fayoum J. Agric. Res. \& Dev., Vol.19, No.2, July, 2005 
Nagat G.M. Aziz, et al.

strength (Richards, 1954), organic matter content (Walkely and Black method as described by Hesse, 1971), $\mathrm{CaCO}_{3}$ content (Wright, 1939), cation exchange capacity, exchangeable sodium per cent, $\mathrm{pH}$ and soil paste extract (Jackson, 1973). Available N, P and $\mathrm{K}$ in soil were extracted by $1 \%$ potassium sulphate, $0.5 \mathrm{M}$ sodium bicarbonate and $1 \mathrm{~N}$ ammonium acetate, respectively (Sultanpour and Schwab, 1977) and their contents in soil were determined according to Jackson (1973). Available micronutrients of Fe, Mn, $\mathrm{Zn}$, and $\mathrm{Cu}$ in soil were extracted using ammonium bicarbonate-DTPA extract according to Lindsay and Norvell (1978) and their contents in soil were measured by using the Atomic Absorption Spectrophotometer.

As for plant samples, many plant parameters were carried out to identify the vegetative growth, i.e., plant height, No. of tillers/plant, No. of leaves/ plant, leaf area/plant and leaves dry weight/plant. At harvest stage, plant samples were separated into grains and straw to determine their components, i.e., 1000 grain weight, protein content $\%$ and nutrients uptake by plant. Crude protein was calculated by multiplying total N-content by 6.25 (Deyoe and Shellenberger, 1965). Plant samples were collected and dried at $70 \mathrm{C}^{\circ}$, ground in a Willy mill and digested with $\mathrm{H}_{2} \mathrm{SO}_{4}$ and $\mathrm{H}_{2} \mathrm{O}_{2}$ according to Parkinson and Allen (1975) to determine N, P, K (Chapman and Pratt, 1961), $\mathrm{Fe}, \mathrm{Mn}, \mathrm{Zn}$ and $\mathrm{Cu}$ (Hesse, 1971).

\section{RESULTS AND DISCUSSION:}

The uncontrolled application of the low quality water at El Fayoum Governorate, especially in the long-term use, was not only restricted effects on both soil properties and growth of the plants grown, but also virtually all the elements of the physico-geographical environments and causes deep-going and prolonged changes in the natural conditions of the locality (Farrag, 2000 and 2003). From this point of view, the current study was carried out to clarify the negative effects of the salinity levels and specific anion of irrigation water on the studied soil properties as compared to the similar ones used the fresh Nile water.

\section{Soil properties as affected by using salinity levels of irrigation water:}

a. Soil chemical properties:

The usage of saline irrigation water considerably affects many soil properties through the concomitant accumulation of salts and their specific anions, which equilibrium in soil solution. Data in Table (2) revealed that the values of soil $\mathrm{pH}$ and ESP tended to increase slightly with increasing salinity levels of irrigation water, with the exception of those irrigated with $\mathrm{Na}_{2} \mathrm{CO}_{3}$ that exhibited progressive increases in both values due to the specific effect of both the free ions of $\mathrm{Na}^{+}$and $\mathrm{CO}_{3}{ }^{2-}$.

The magnitudes of soil $\mathrm{pH}$ and ESP values in the studied soil as affected by the applied irrigation water salinity levels are shown in the following order: $\mathrm{Na}_{2} \mathrm{CO}_{3}>\mathrm{NaCl} \geq \mathrm{Na}_{2} \mathrm{SO}_{4}$. Data presented in Table (2) also revealed that the continuous usage of saline irrigation water built up salts in irrigated soils, which exerted certain changes in soil properties as mentioned before. The accumulated salts were proportionally increased with increasing the salinity levels of irrigation water. This is evidently by the pronounced high ECe of soils irrigated with $\mathrm{Na}_{2} \mathrm{CO}_{3}$, may be created by the specific ions effect $\left(\mathrm{Na}^{+}\right.$

Fayoum J. Agric. Res. \& Dev., Vol.19, No.2, July, 2005 
IMPACT OF APPLYING SALINITY LEVELS AND SPECIFIC.

and $\mathrm{CO}_{3}{ }^{2-}$ ) on depressing the volume of drainable pores due to the degradation of soil aggregates and the dispersion of soil particles.

Table (2): Effect of applied salinity levels and specific anions of irrigation water on soil salinity and soluble ion distribution patterns.

\begin{tabular}{|c|c|c|c|c|c|c|c|c|c|c|c|c|}
\hline \multirow{2}{*}{$\begin{array}{l}\vec{F} \\
\stackrel{\pi}{\sim}\end{array}$} & \multirow{2}{*}{$\begin{array}{c}\text { Salt } \\
\text { conc. } \\
(\mathrm{mg} / \mathrm{L})\end{array}$} & \multirow{2}{*}{$\begin{array}{c}\text { Soil } \\
\mathrm{pH}\end{array}$} & \multirow{2}{*}{ ESP } & \multirow{2}{*}{$\begin{array}{c}\mathrm{ECe} \\
(\mathrm{dS} / \mathrm{m})\end{array}$} & \multicolumn{4}{|c|}{ Soluble cations $(\mathrm{me} / \mathrm{L})$} & \multicolumn{4}{|c|}{ Soluble anions $(\mathrm{me} / \mathrm{L})$} \\
\hline & & & & & $\mathrm{Ca}^{2+}$ & $\mathrm{Mg}^{2+}$ & $\mathrm{Na}^{+}$ & $\mathrm{K}^{+}$ & $\mathrm{CO}_{3}{ }^{2-}$ & $\mathrm{HCO}_{3}^{-}$ & $\mathrm{Cl}^{-}$ & $\mathrm{SO}_{4}{ }^{2-}$ \\
\hline \multicolumn{2}{|c|}{ Control treat.* } & 7.90 & 9.12 & 5.89 & 24.15 & 11.95 & 22.30 & 0.80 & 0.00 & 2.90 & 35.2 & 21.10 \\
\hline \multirow{4}{*}{$\begin{array}{l}\vec{J} \\
\ddot{Z}\end{array}$} & 750 & 7.75 & 10.71 & 6.36 & 20.60 & 16.00 & 26.90 & 0.8 & 0.00 & 3.00 & 45.50 & 15.80 \\
\hline & 1500 & 7.80 & 13.95 & 7.35 & 19.20 & 17.30 & 37.70 & 0.95 & 0.00 & 2.80 & 53.00 & 18.40 \\
\hline & 3000 & 7.85 & 17.20 & 9.18 & 17.40 & 13.30 & 61.00 & 1.10 & 0.00 & 2.75 & 65.00 & 25.05 \\
\hline & 4500 & 7.95 & 19.53 & 12.10 & 16.90 & 11.70 & 92.90 & 1.20 & 0.00 & 2.60 & 90.00 & 30.10 \\
\hline \multirow{4}{*}{$\begin{array}{l}0 \\
\text { U్, } \\
\tilde{Z}\end{array}$} & 750 & 8.65 & 12.74 & 8.87 & 28.60 & 16.80 & 43.40 & 0.90 & 0.60 & 5.20 & 52.00 & 31.90 \\
\hline & 1500 & 8.95 & 18.90 & 12.20 & 33.35 & 28.00 & 61.20 & 1.35 & 2.40 & 7.80 & 64.20 & 49.50 \\
\hline & 3000 & 9.95 & 24.85 & 16.60 & 34.80 & 36.20 & 95.30 & 1.50 & 4.20 & 10.60 & 97.00 & 56.00 \\
\hline & 4500 & 10.45 & 30.32 & 19.10 & 41.90 & 36.30 & 113.2 & 1.80 & 6.50 & 12.30 & 122.0 & 52.40 \\
\hline \multirow{4}{*}{ 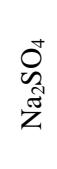 } & 750 & 7.55 & 9.65 & 5.98 & 17.00 & 13.05 & 29.50 & 0.85 & 0.00 & 2.70 & 33.00 & 24.70 \\
\hline & 1500 & 7.70 & 10.20 & 6.61 & 17.50 & 11.00 & 37.40 & 1.00 & 0.00 & 2.60 & 25.00 & 39.30 \\
\hline & 3000 & 7.75 & 12.87 & 8.59 & 20.10 & 16.80 & 47.60 & 1.20 & 0.00 & 2.40 & 30.40 & 52.90 \\
\hline & 4500 & 7.80 & 13.91 & 9.14 & 19.60 & 15.10 & 53.80 & 1.40 & 0.00 & 2.40 & 31.00 & 56.50 \\
\hline
\end{tabular}

On basis of ECe value, there are differences in the values of salinity build up through applying $\mathrm{NaCl}$ and $\mathrm{Na}_{2} \mathrm{SO}_{4}$ solutions as compared to $\mathrm{Na}_{2} \mathrm{CO}_{3}$ after about 80 days of planting, however, the results indicated that built up soil salinity was influenced not only by salinity level of irrigation water but also by the pattern of specific ions. As a general view, soil salinity tended to increase slightly in the case of applying $\mathrm{NaCl}$ and $\mathrm{Na}_{2} \mathrm{SO}_{4}$ solutions, probably due to the formation of false soil aggregates that caused sufficient soil drainage, and in turn enhanced the removal of some excess salts under the flooding system. Whereas, data cleared that, raising salinity levels of $\mathrm{Na}_{2} \mathrm{CO}_{3}$ solution greatly increased soil salinity, where the relative increases in ECe of soils irrigated with $\mathrm{Na}_{2} \mathrm{CO}_{3}$ at the highest salinity level of $4500 \mathrm{mg} / \mathrm{L}$ reached more than 1.5 and 2.0 folds of those irrigated with $\mathrm{NaCl}$ and $\mathrm{Na}_{2} \mathrm{SO}_{4}$ solutions, respectively.

Concerning the distribution pattern of soluble ions, data in Table (2) indicated that, actually, the magnitude of ions increase was proportional to the chemical composition of the irrigation water used. This is because alternating saline water provokes replacement of soil solution, and thus results in different ionic concentrations in the soil solution. In general, the distribution pattern of soluble cations in soils irrigated with the applied saline irrigation water followed the descending order of $\mathrm{Na}^{+}>\mathrm{Ca}^{2+}>\mathrm{Mg}^{2+}>\mathrm{K}^{+}$, while the soluble anions could be arranged as $\mathrm{Cl}^{-} \geq \mathrm{SO}_{4}{ }^{2-}>\mathrm{HCO}_{3}{ }^{-}$. The corresponding cation and anion patterns in soils irrigated with the Nile water was $\mathrm{Ca}^{2+}>\mathrm{Na}^{+}>\mathrm{Mg}^{2+}>$ $\mathrm{K}^{+}$, and $\mathrm{Cl}^{-}>\mathrm{SO}_{4}{ }^{2-}>\mathrm{HCO}_{3}{ }^{-}$, respectively. The $\mathrm{Na}^{+}$content reached more than 3-4 folds of $\left(\mathrm{Ca}^{2+}+\mathrm{Mg}^{2+}\right)$ content. $\mathrm{Cl}^{-}$or $\mathrm{SO}_{4}{ }^{2-}$ were dominated the anionic composition indicating that $\mathrm{NaCl}$ and $\mathrm{Na}_{2} \mathrm{SO}_{4}$ were the dominant salts, and such behaviour is conductive to unproductive sodic soils.

Fayoum J. Agric. Res. \& Dev., Vol.19, No.2, July, 2005 
Nagat G.M. Aziz, et al.

\section{b. Soil hydrophysical properties:}

Data illustrated in Table (3) showed that irrigation with the tested saline waters left their hazardous footprints on the different soil properties. The changes in soil characteristics depended on water salinity levels. Soil bulk density is more related to various physical properties (Lawrence, 1977).

Table (3): Effect of applied salinity levels and specific anions of irrigation water on the studied soil hydrophysical properties.

\begin{tabular}{|c|c|c|c|c|c|c|c|}
\hline \multirow[b]{2}{*}{ 总 } & \multirow[b]{2}{*}{ 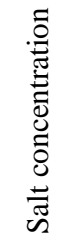 } & \multicolumn{6}{|c|}{ Soil hydrophysical properties } \\
\hline & & 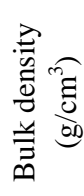 & 㻤 & 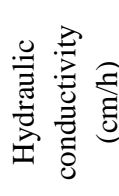 & 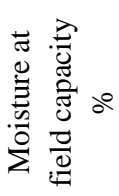 & 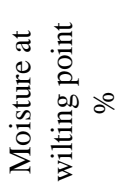 & 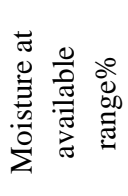 \\
\hline \multicolumn{2}{|c|}{ Control treatment* } & 1.21 & 50.97 & 1.42 & 34.21 & 14.13 & 20.03 \\
\hline \multirow{4}{*}{$\begin{array}{l}\bar{E} \\
\bar{Z}\end{array}$} & 750 & 1.24 & 49.39 & 1.31 & 32.21 & 14.95 & 17.26 \\
\hline & 1500 & 1.29 & 47.35 & 1.12 & 30.01 & 16.53 & 13.48 \\
\hline & 3000 & 1.35 & 44.90 & 0.93 & 29.07 & 17.10 & 11.97 \\
\hline & 4500 & 1.39 & 43.26 & 0.84 & 27.81 & 17.56 & 10.25 \\
\hline \multirow{4}{*}{ 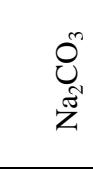 } & 750 & 1.26 & 48.57 & 1.25 & 31.91 & 16.75 & 15.16 \\
\hline & 1500 & 1.33 & 45.71 & 0.95 & 29.82 & 18.37 & 11.45 \\
\hline & 3000 & 1.40 & 42.86 & 0.67 & 29.61 & 19.76 & 9.85 \\
\hline & 4500 & 1.45 & 40.82 & 0.54 & 28.57 & 20.15 & 8.42 \\
\hline \multirow{4}{*}{$\begin{array}{l}0^{+} \\
\text {స్ } \\
\text { Zे }\end{array}$} & 750 & 1.23 & 49.80 & 1.36 & 32.29 & 14.22 & 18.07 \\
\hline & 1500 & 1.26 & 48.56 & 1.21 & 30.30 & 14.76 & 15.54 \\
\hline & 3000 & 1.30 & 46.94 & 1.10 & 29.71 & 15.93 & 13.78 \\
\hline & 4500 & 1.32 & 46.12 & 1.03 & 29.48 & 16.42 & 13.06 \\
\hline
\end{tabular}

* Irrigated with the Nile water

Data obtained revealed that soil bulk density values gradually increased with increasing soil salinity (Table, 2), which was more related to the salinity level of the applied irrigation water. This trend could be attributed to the negative effects of Na-salts on dispersion of soil aggregates. These findings are in agreement with those obtained by Batey (1990) who reported that soil bulk density was closely related to solid properties and pore space, which depend upon the changes in soil texture and other factors, i.e., soil salinity and alkalinity. It is quite noticeable that the change rates in soil bulk density depended on water salinity levels, where it increased with increasing water salinity levels.

With respect to soil total porosity as related to water salinity levels, data revealed that the percentage of total porosity tended to decrease with increasing the salinity levels of the applied irrigation water. This trend could be attributed to the relatively higher ESP value, which tended to be more than $30 \%$ in the treated soil, as shown in Table (2).

Data in Table (3) showed a pronounced decrease in soil available water range with increasing salinity level of applied irrigation water as compared to soil irrigated with the Nile fresh water. This could be explained on the basis that increasing soil salinity decreased soil moisture content at field capacity

Fayoum J. Agric. Res. \& Dev., Vol.19, No.2, July, 2005 
IMPACT OF APPLYING SALINITY LEVELS AND SPECIFIC.

and increased moisture content at wilting point in the same time, consequently decreased the available water range. The relatively high soil moisture retained at wilting point may be ascribed to the effect of both matrix and osmotic potentials on increasing the ability of the treated soils to retain water.

Soil permeability (hydraulic conductivity) depends on many factors, especially the volume of drainable pores. The previous data indicated that applying saline irrigation water led to increase in soil total porosity vs depressing the volume of drainable pores, due to the degradation of soil aggregates and the dispersion of soil particles created by ESP value, which approached more than $30 \%$. Thus, the values of hydraulic conductivity tended to decrease with increasing the salinity level of both irrigation water and soils irrigated with it.

\section{c. Soil fertility status:}

The available contents of some chemically extractable macronutrients $(\mathrm{N}, \mathrm{P}$ and $\mathrm{K})$ and micronutrients $(\mathrm{Fe}, \mathrm{Mn}, \mathrm{Zn}$ and $\mathrm{Cu})$ contents are given in Table (4). The obtained data indicated that the contents of the studied macro and micronutrients in soils irrigated with the tested saline water exhibited relatively low values as compared to those irrigated with the fresh Nile water, with the exception of $\mathrm{K}$ as well as Fe and Mn, especially in the soils that were subjected directly to a relatively high salinity level of irrigation water. These results stand in well agreement with those obtained by El Toukhy (1987), who found that there was a highly significant and positive correlation between available $\mathrm{K}$ in soil and salinity of irrigation water due to enhancing the released of $\mathrm{K}$ from K-bearing minerals or K-enrichment. As for $\mathrm{Fe}$ and $\mathrm{Mn}$, the relative increases were more attributed to the dominant of di-equivalent forms of $\mathrm{Fe}^{2+}$ and $\mathrm{Mn}^{2+}$ under the reduction zone due to the influence of the unsuitable air-moisture regime (poor-aeration).

In general, the relative decrease in available nutrient contents may be attributed to the unsuitable soil conditions that control the availability of nutrients, beside the depressive effect of salinity stress of both irrigation water and soil on plant growth, consequently decreasing the crop residues remained in soil. These findings are supported by those obtained by Hegazi (1999) who found a negative correlation between salinity and available plant nutrients in soil.

Fayoum J. Agric. Res. \& Dev., Vol.19, No.2, July, 2005 
Nagat G.M. Aziz, et al.

Table (4): Effect of applied salinity levels and specific anions of irrigation water on the available nutrient contents in soil.

\begin{tabular}{|c|c|c|c|c|c|c|c|c|c|}
\hline \multirow{3}{*}{ 馬 } & \multirow{3}{*}{\multicolumn{2}{|c|}{ 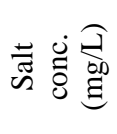 }} & \multicolumn{7}{|c|}{ Available macro and micronutrients in soil } \\
\hline & & & \multicolumn{3}{|c|}{ Macronutrients \% } & \multicolumn{4}{|c|}{ Micronutrients $(\mathrm{mg} / \mathrm{kg})$} \\
\hline & & & $\mathrm{N}$ & $\mathrm{P}$ & $\mathrm{K}$ & $\mathrm{Fe}$ & $\mathrm{Mn}$ & $\mathrm{Zn}$ & $\mathrm{Cu}$ \\
\hline \multicolumn{3}{|c|}{ Control treat.* } & 42.73 & 5.62 & 352.74 & 6.49 & 2.47 & 1.39 & 1.18 \\
\hline \multirow{4}{*}{$\begin{array}{l}\bar{\Xi} \\
\bar{Z}\end{array}$} & \multicolumn{2}{|c|}{750} & 39.50 & 5.08 & 359.36 & 5.93 & 2.03 & 1.27 & 1.12 \\
\hline & \multicolumn{2}{|c|}{1500} & 35.15 & 4.52 & 367.90 & 5.15 & 1.34 & 1.16 & 1.00 \\
\hline & \multicolumn{2}{|c|}{3000} & 31.94 & 3.99 & 371.25 & 4.78 & 1.17 & 1.08 & 0.91 \\
\hline & \multicolumn{2}{|c|}{4500} & 29.45 & 3.48 & 375.05 & 4.36 & 1.02 & 0.92 & 0.84 \\
\hline \multirow{4}{*}{ 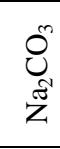 } & \multicolumn{2}{|c|}{750} & 36.80 & 4.64 & 355.36 & 7.20 & 2.95 & 1.14 & 1.02 \\
\hline & \multicolumn{2}{|c|}{1500} & 30.05 & 3.87 & 358.12 & 8.49 & 3.47 & 0.90 & 0.93 \\
\hline & \multicolumn{2}{|c|}{3000} & 23.86 & 3.23 & 360.95 & 10.58 & 4.23 & 0.78 & 0.75 \\
\hline & \multicolumn{2}{|c|}{4500} & 21.07 & 2.91 & 361.32 & 11.92 & 4.56 & 0.74 & 0.59 \\
\hline \multirow{4}{*}{ 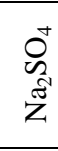 } & \multicolumn{2}{|c|}{750} & 40.13 & 5.34 & 362.55 & 6.25 & 2.21 & 1.32 & 1.15 \\
\hline & \multicolumn{2}{|c|}{1500} & 37.80 & 5.07 & 387.01 & 5.94 & 1.89 & 1.20 & 1.08 \\
\hline & \multicolumn{2}{|c|}{3000} & 35.52 & 4.65 & 392.67 & 5.67 & 1.50 & 1.12 & 0.99 \\
\hline & \multicolumn{2}{|c|}{4500} & 36.92 & \begin{tabular}{l|l} 
& 4.32 \\
\end{tabular} & 397.41 & 5.23 & 1.38 & 1.06 & 0.91 \\
\hline \multicolumn{10}{|c|}{ Critical limits of nutrients in $\mathrm{mg} / \mathrm{kg} *$} \\
\hline \multicolumn{2}{|c|}{ Limits } & \multicolumn{2}{|c|}{$\mathrm{N}$} & $\mathrm{P}$ & $\mathrm{K}$ & $\mathrm{Fe}$ & Mn & $\mathrm{Zn}$ & $\mathrm{Cu}$ \\
\hline \multicolumn{2}{|c|}{ Low } & \multicolumn{2}{|c|}{$<40.0$} & $<5.0$ & $<85.0$ & $<4.0$ & $<2.0$ & $<1.0$ & $<0.5$ \\
\hline \multicolumn{2}{|c|}{ Medium } & \multicolumn{2}{|c|}{$40.0-80.0$} & $5.0-10.0$ & $85.0-170.0$ & $4.0-6.0$ & $2.0-5.0$ & $1.0-2.0$ & $0.5-1.0$ \\
\hline \multicolumn{2}{|c|}{ High } & \multicolumn{2}{|c|}{$>80.0$} & $>10.0$ & $>170$ & $>6.0$ & $>5.0$ & $>2.0$ & $>1.0$ \\
\hline
\end{tabular}

*Critical levels of nutrients after Lindsay and Norvell (1978) and Page et al. (1982)

* Irrigated with the Nile water

\section{Characteristics of grown barley plants as affected by the applied saline irrigation water:}

a. Vegetative growth parameters:

The continuous application of saline water for irrigating the grown plants is drastically associated with excess of salts or specific ions that accumulate in both soil and plant. Consequently, the depressive effect of salt stress on plant growth and its uptake or ability to accumulate in plant tissues at a hazard level became a matter of consideration in this part of study. Data illustrated in Table (5) represent a trial to determine the negative impact of water salinity stress on some vegetative growth parameters, i.e., plant height, No. of tillers/plant, No. of leaves/plant, leaf area/plant and leaves dry weight/plant.

In this respect, results indicated that any increase in salinity level of either irrigation water or soil was associated with a decrease in all the studied vegetative parameters. That means there are an inverse relation between water salinity levels and plant growth parameters, where it can be deduced that the higher the water salinity the lower vegetative parameters under investigation.

It is worthy to mention that the magnitudes of reduction differed from trait to another, the highest reduction was observed with the number of tillers/plant, while the least occurred with plant height. The reductions in growth parameters may be due to decreasing the net photosynthesis, stomata conductance and transpiration rate under salinity stress of irrigation water (Naire and Khuble, 1990).

Fayoum J. Agric. Res. \& Dev., Vol.19, No.2, July, 2005 
IMPACT OF APPLYING SALINITY LEVELS AND SPECIFIC.

Table (5): Effect of applied salinity levels and specific anions of irrigation water on the studied vegetative growth parameters of barley.

\begin{tabular}{|c|c|c|c|c|c|c|}
\hline \multirow[b]{2}{*}{$\frac{ \pm}{\tilde{n}}$} & \multirow{2}{*}{ 慈 } & \multicolumn{5}{|c|}{ Growth characters per plant } \\
\hline & & $\begin{array}{c}\text { Height } \\
(\mathrm{cm})\end{array}$ & $\begin{array}{l}\text { No. of } \\
\text { tillers }\end{array}$ & $\begin{array}{l}\text { No. of } \\
\text { leaves }\end{array}$ & $\begin{array}{l}\text { Leaves dry } \\
\text { weight }(\mathrm{g})\end{array}$ & $\begin{array}{l}\text { Leaf area } \\
\quad\left(\mathrm{cm}^{2}\right)\end{array}$ \\
\hline \multicolumn{2}{|c|}{ Control treat.* } & 58.95 & 3.6 & 10.8 & 6.59 & 13.6 \\
\hline \multirow{4}{*}{$\begin{array}{l}\overline{\tilde{Z}} \\
\bar{Z}\end{array}$} & 750 & 54.34 & 3.2 & 9.9 & 6.37 & 12.9 \\
\hline & 1500 & 52.96 & 2.9 & 9.6 & 6.21 & 11.7 \\
\hline & 3000 & 51.02 & 2.7 & 8.3 & 6.10 & 10.8 \\
\hline & 4500 & 49.35 & 2.5 & 8.7 & 5.70 & 10.2 \\
\hline \multirow{4}{*}{$\begin{array}{l}\overbrace{0}^{\prime} \\
\text { Z }\end{array}$} & 750 & 49.12 & 2.8 & 8.9 & 5.82 & 11.2 \\
\hline & 1500 & 46.67 & 2.5 & 8.3 & 5.73 & 10.6 \\
\hline & 3000 & 45.09 & 2.4 & 7.6 & 5.56 & 9.8 \\
\hline & 4500 & 43.82 & 2.1 & 7.2 & 5.45 & 9.4 \\
\hline \multirow{4}{*}{$\begin{array}{l}0^{+} \\
\mathscr{E}^{+} \\
\tilde{Z}^{-}\end{array}$} & 750 & 57.10 & 3.5 & 10.3 & 6.43 & 13.1 \\
\hline & 1500 & 55.64 & 3.3 & 10.0 & 6.36 & 12.6 \\
\hline & 3000 & 54.53 & 3.2 & 9.8 & 6.25 & 12.0 \\
\hline & 4500 & 53.17 & 3.0 & 9.6 & 6.07 & 11.5 \\
\hline
\end{tabular}

\section{b. Elemental composition of barley plants:}

The relative decreases in nutrient contents of grown barley plants irrigated with relatively high salinity levels as compared to the expected ones in that cultivated under the normal conditions are illustrated in Table (6).

Table (6): Effect of applied salinity levels and specific anions of irrigation water on the nutrient concentrations in the grown barley plants.

\begin{tabular}{|c|c|c|c|c|c|c|c|c|}
\hline \multirow{3}{*}{$\frac{\vec{H}}{\tilde{n}}$} & \multirow{3}{*}{ 莞 } & \multicolumn{7}{|c|}{ Nutrient tissue concentrations } \\
\hline & & \multicolumn{3}{|c|}{ Macronutrients \% } & \multicolumn{4}{|c|}{ Micronutrients (mg/kg) } \\
\hline & & $\mathrm{N}$ & $\mathrm{P}$ & $\mathrm{K}$ & $\mathrm{Fe}$ & $\mathrm{Mn}$ & $\mathrm{Zn}$ & $\mathrm{Cu}$ \\
\hline \multicolumn{2}{|c|}{ Control treat.* } & 2.13 & 0.38 & 2.59 & 137 & 89 & 70 & 23 \\
\hline \multirow{4}{*}{$\begin{array}{l}\bar{\Xi} \\
\bar{Z}\end{array}$} & 750 & 1.89 & 0.33 & 2.21 & 113 & 79 & 59 & 19 \\
\hline & 1500 & 1.74 & 0.32 & 2.04 & 101 & 71 & 53 & 16 \\
\hline & 3000 & 1.63 & 0.29 & 1.86 & 91 & 64 & 45 & 13 \\
\hline & 4500 & 1.56 & 0.27 & 1.75 & 83 & 58 & 39 & 12 \\
\hline \multirow{4}{*}{ 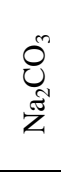 } & 750 & 1.67 & 0.28 & 1.98 & 98 & 62 & 50 & 16 \\
\hline & 1500 & 1.58 & 0.25 & 1.72 & 91 & 55 & 42 & 14 \\
\hline & 3000 & 1.49 & 0.24 & 1.53 & 82 & 49 & 36 & 11 \\
\hline & 4500 & 1.42 & 0.22 & 1.42 & 71 & 44 & 31 & 9 \\
\hline \multirow{4}{*}{$\begin{array}{l}0^{+} \\
\tilde{W}^{+} \\
\tilde{Z}^{-}\end{array}$} & 750 & 2.05 & 0.35 & 2.31 & 123 & 83 & 65 & 21 \\
\hline & 1500 & 1.93 & 0.33 & 2.23 & 115 & 77 & 60 & 19 \\
\hline & 3000 & 1.84 & 0.32 & 2.12 & 108 & 72 & 53 & 18 \\
\hline & 4500 & 1.76 & 0.30 & 1.98 & 99 & 69 & 48 & 16 \\
\hline
\end{tabular}

*Irrigated with the Nile water

Fayoum J. Agric. Res. \& Dev., Vol.19, No.2, July, 2005 
Nagat G.M. Aziz, et al.

This adverse effect was not only reflected the restriction of supplying power for available nutrients in the studied soils, but also the influence of the unsuitable environmental conditions in the root zone, especially air-moisture regime that controlled the biological mechanism of nutrients uptake by plant roots, as shown for $\mathrm{Fe}^{2+}$ and $\mathrm{Mn}^{2+}$. This could be attributed to the depressive effect of osmotic potential on plant growth and specific ion effect on the mechanism of nutrients uptake from the growth media (Amer, 1999). In such calcareous soil, the restriction of phosphorus and micronutrients availability is confirmed by the occurrence of sodication and lime carbonation or released $\mathrm{Ca}^{2+}$. Also, it is evident that the relatively high soil salinity leads to an uptake inhibition of plant roots for all nutrients, due to the inability of subcellular osmotic units to adjust the relatively high osmotic pressure and ionic strength (Khater et al. (2002).

c. Barley yield and its components:

Data in Table (7) showed the effects of irrigation water salinity levels on barley yield and its components. Gradual decreases were observed in their values due to raising the levels of irrigation water salinity. Soil irrigated with $\mathrm{Na}_{2} \mathrm{CO}_{3}$ solution showed a great decrease in barley yield and its components as compared to those irrigated with $\mathrm{NaCl}$ and $\mathrm{Na}_{2} \mathrm{SO}_{4}$ solutions. This harmful effect might be more related to the specific ions effect of $\mathrm{Na}^{+}$and $\mathrm{CO}_{3}{ }^{2-}$ either as a direct effect on the grown plants or indirect effect through their hazardous effect on soil properties. Most of theses reductions resulted from the decreases in numbers of grains per spike or plant rather than the decrease in 1000 grain weight, which seems to be almost stable against the changes of irrigation water salinity levels.

Table (7): Effect of applied salinity levels and specific anions of irrigation water on barley yield and its attributes.

\begin{tabular}{|c|c|c|c|c|c|c|}
\hline $\begin{array}{l}\text { 馬 } \\
\text { ñ }\end{array}$ & 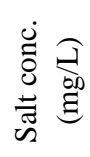 & 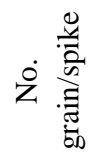 & 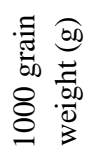 & 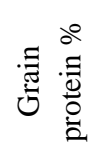 & $\begin{array}{c}\text { Straw } \\
\text { yield } \\
(\mathrm{g} / \text { pot })^{*}\end{array}$ & $\begin{array}{c}\text { Grain } \\
\text { yield } \\
(\mathrm{g} / \text { pot })^{*}\end{array}$ \\
\hline \multicolumn{2}{|c|}{ Control treat.** } & 41.3 & 38.60 & 1.371 & 12.97 & 14.67 \\
\hline \multirow{4}{*}{$\begin{array}{l}\bar{E} \\
\tilde{Z}\end{array}$} & 750 & 37.64 & 37.98 & 12.92 & 10.68 & 12.03 \\
\hline & 1500 & 35.52 & 37.06 & 11.03 & 10.21 & 10.94 \\
\hline & 3000 & 33.95 & 36.75 & 10.35 & 9.43 & 10.20 \\
\hline & 4500 & 32.05 & 3659 & 9.81 & 8.75 & 9.98 \\
\hline \multirow{4}{*}{$\begin{array}{l}\bigcup^{\infty} \\
\underbrace{N}\end{array}$} & 750 & 30.15 & 36.95 & 12.10 & 10.06 & 11.22 \\
\hline & 1500 & 27.60 & 36.37 & 10.55 & 8.94 & 10.74 \\
\hline & 3000 & 25.91 & 3574 & 9.62 & 8.13 & 9.56 \\
\hline & 4500 & 24.86 & 34.92 & 8.87 & 7.94 & 8.93 \\
\hline \multirow{4}{*}{$\begin{array}{l}0^{+} \\
\mathscr{W}^{+} \\
\tilde{Z}^{-}\end{array}$} & 750 & 39.54 & 38.13 & 13.02 & 12.20 & 13.65 \\
\hline & 1500 & 38.13 & 37.85 & 12.54 & 11.56 & 12.71 \\
\hline & 3000 & 36.99 & 37.20 & 11.65 & 10.64 & 11.55 \\
\hline & 4500 & 35.71 & 37.11 & 11.00 & 9.82 & 10.74 \\
\hline
\end{tabular}

* Eight barley plants ** Irrigated with the Nile water

Fayoum J. Agric. Res. \& Dev., Vol.19, No.2, July, 2005 
Also, the reductions in straw yield, which amounted about $24-39 \%$ at the highest water salinity level as compared to the control treatment, were a function of the decrease in plant height in a minor magnitude due to tillering capacity of relatively major magnitude.

From the abovementioned discussion it is evident that the hazardous effects of irrigation water salinity stress could be referred to greatest growth inhibition under the continuous irrigation with highly saline water. In addition, the continuous usage of saline irrigation water built up salts in irrigated soils, which exerted certain changes in soil properties as mentioned before. The accumulated salts were proportionally increased with increasing the salinity levels of irrigation water. This is evidently by the pronounced high ECe of soils irrigated with $\mathrm{Na}_{2} \mathrm{CO}_{3}$, may be created by the specific ions effect $\left(\mathrm{Na}^{+}\right.$ and $\mathrm{CO}_{3}{ }^{2-}$ ) on depressing the volume of drainable pores due to the degradation of soil aggregates and the dispersion of soil particles. So, the mixing of saline water with the Nile fresh one at a suitable salinity level should be recommended, especially in the relatively fine textured soils that have unfavourable soil drainage conditions or those have unsuitable drainage system.

\section{REFERENCES:}

Abdel Aziz, Z.H. (2004): Effect of salinity on availability of some nutrients in soil. M. Sc. Thesis, Fac. of Agric., Moshtohor, Zagazig Univ., Egypt.

Ahmad, I.A.; A.M. El Sherbini; A.M.O El Bowab; M.A. El Moseilhy and E.M. Salem (1998): Effect of soil salinity on grain yield and nutrition quality of some barley genotypes. Egypt. J. Appl. Sci., 13(3): 93-99.

Amer, A.F. (1999): Effect of salinity stress, increasing gradually and suddenly treatment, on plant nutrient uptake and content of some carbohydrate fractions. Egypt. J. Soil Sci., 39 (1): 111-128.

Batey, T. (1990): Control of compaction on the farm; A personal view. Soil Technology, 3: 225-229.

Bayoumi, N.A.; M.S. Omran; M.A. Negm and S.S. Mahammed (1997): Effect of irrigation water quality on barley grown on a calcareous soil. Egypt. J. Soil Sci., 37(1): 29-45.

Black, C.A. (1965): Methods of Soil Analysis. Part I, Published by the American Society of Agronomy, Wisconsin, USA.

Black, G.R. and K.H. Hartge (1986): Bulk density. In: Methods of Soil Analysis. Part 1, Klute, A. (Ed.), Agronomy Monograph No. 9: 363.

Chapman, H.D. and P.F. Pratt (1961): Methods of Analysis for Soils, Plants and Waters. Univ. of California, Riverside, U.S.A.

Deyoe, C.W. and J.A. Shellenberger (1965): Amino acids and proteins in sorghum grain. J. Agric. and food Chem., 13:446.

El Gala, A.M.; M.A. mostafa and S.E. El Maghraby (1989): Infuence of sulfur and saline irrigation water on growth and elements status of barley plant grown on calcareous soils. Egypt. J. Soil Sci., Special Issue, pp. 443455.

El Tapey, H.M.A. and H.M. Hassan (2002): Effect of water salinity and zinc applications on zinc mobility and growth of sunflower and sudangrass plants grown on Nile alluvial and calcareous soils. Egypt. J. Appl. Sci., 17 (12): 840-849.

Fayoum J. Agric. Res. \& Dev., Vol.19, No.2, July, 2005 
Nagat G.M. Aziz, et al.

EI Tapey, H.M.A.; A.A. Hagag and I.A. El Gammal (2005): Impact of irrigation water salinity on growth, yield and elemental composition of barley under some soil amendments application in a newly reclaimed soil. J. Agric. Sci., Mansoura Univ., 30 (1): 689-699

El Toukhy, M.M. (1987): Studies on the status of some nutritive elements in the soil adjacent to Idko lake (Behiera Governorate). M. Sc. Thesis, Fac. of Agric., Cairo Univ., Egypt.

Farrag, R.M.F. (2000): Potential effects of low quality water for soil irrigation in El Fayoum Governorate, Egypt. M. Sc. Thesis, Fac. of Agric. at El Fayoum, Cairo Univ., Egypt.

Farrag, R.M.F. (2003): Land degradation as affected by irrigation water quality in El Fayoum Governorate. Ph. D. Thesis, Fac. of Agric. at El Fayoum, Cairo Univ., Egypt.

Gupta, I.C. (1990); Use of Saline Water in Agriculture. Publishing Co.Pvt Ltd,66 janpath, New Delhi, 110001.

Hegazi, I.M.A. (1999): Factors affecting utilization and development in lands and water resources of the northern area of El Fayoum. Ph. D. Thesis, Fac. of Agric. at El Fayoum, Cairo Univ., Egypt.

Hesse, P.R. (1971) : A Text-Book of Soil Chemical Analysis. John Murray, London, Great Britain .

Jackson, M.L.(1973): Soil Chemical Analysis. Prentice Hall of India Private Limited, New Delhi. Indian.

Khatr, E.A.; A.A. Awadalla and Sh.E.B. Ibrahim (2002): Some desertification aspects as related to soil fertility status. Proceeding of the Second Conference "Sustainable Agricultural Development", El Fayoum Fac. of Agric., May 8-10, pp. 129-146.

Klute, A. Ed. (1986): Methods of Soil Analysis. No. 9 Part 1, Amer. Soc. Agron., Inc. Madison, Wisconsin, USA.

Lawrence, G.P. (1977): Measurement of pore size in fine textured soils: A review of existing techniques. J. Soil Sci., 28: 527-540.

Lindsay, W.L. and Norvell, W.A. (1978): Development of DTPA soil test for Zn, Fe, Mn and Cu. Soil Sci. Soc. Am. J., 42: 421-428.

Megahed, M.A. and E.M. Gaafer (2003): Estimation of salt tolerance and productivity of some barley varieties under two irrigation water salinity levels at Ras Sudr. J. Agric. Sci., Mansoura Univ., 28 (1): 11-22.

Naire, k.P.p and N.C. Khuble (1990): Different respose of wheat and barley genotypes to substrate induced salinity under north Indian conditions. Exp. Agric., 26: 221-225.

Page, A.I.; Miller, R.H. and Keeney, D.R, (Eds.) (1982): Methods of Soil Analysis. Part 2: Chemical and Microbiological Properties. $2 \stackrel{n d}{~ E d i t i o n, ~}$ Amer. Soc. of Agron., Madison, Wisconsin, U.S.A.

Parkinson, J.A. and Allen, S.E. (1975): Ewer oxidation procedure suitable for the determination of nitrogen and mineral nutrients in biological material. Commun. Soil Sci. Plant Analysis, 6: 1-11.

Richards, L.A. (1954): Diagnosis and Improvement of Saline and Alkali Soils. U.S. Dept. of Agric., Hand Book No. 60.

Fayoum J. Agric. Res. \& Dev., Vol.19, No.2, July, 2005 
IMPACT OF APPLYING SALINITY LEVELS AND SPECIFIC.

Sultanpour, P.N. and Schwab, A.B. (1977): A new soil test for simultaneous extraction of micronutrients in alkaline soils. Comm. Soil Sc. and Plant Annal., 8: 195.

Wilcox, L.V. and W.H. Durrum (1967): Quality of irrigation water. Pp. 104122: In: R.M. Hafen (Ed.): Irrigation of Agricultural Lands. Agronomy Monograph No. II, SAS, Inc, Madison, Wisconsin.

Wright, C.H. (1939): Soil Analysis. Thomas Murby and Co., London.

Yallon, D.H. (1957): Problems of soil testing on calcareous soils. Plant and Soil, 8: 275-288.

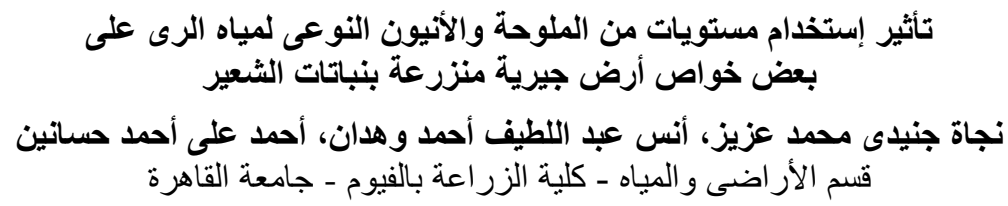

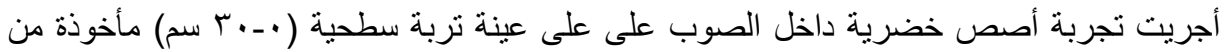

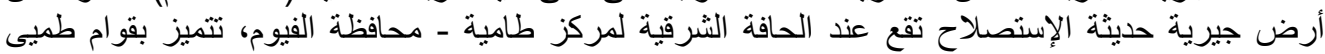

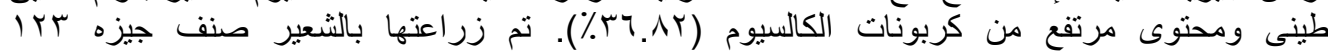

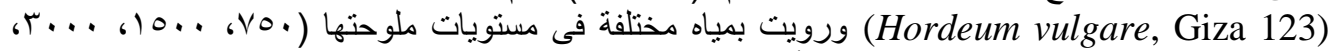

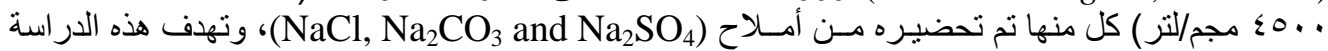
إلى تحديد مدى إستجابة صفات كل من التربة والثعير النامى للتركيز الكلى للأملاح والتأثير النوعى التهى للأنيونات

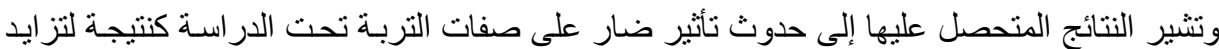

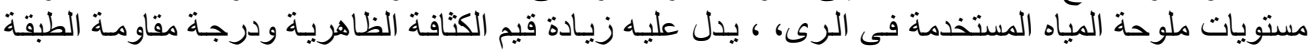

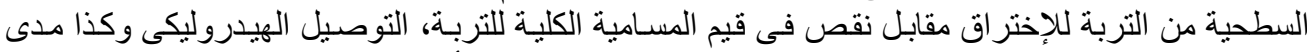

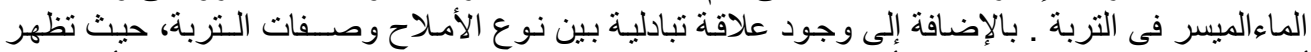

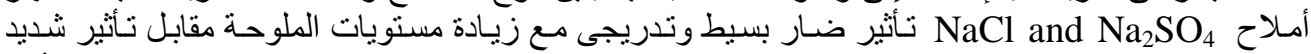
الضرر فى حالة

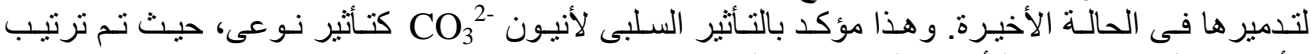
$\mathrm{CO}_{3}^{2-}>\mathrm{Cl}^{-}>\mathrm{SO}_{4}^{2-}$

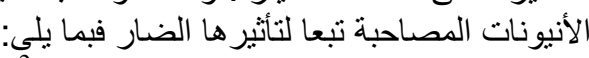

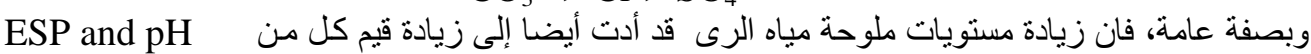

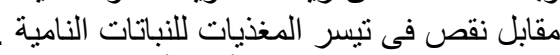

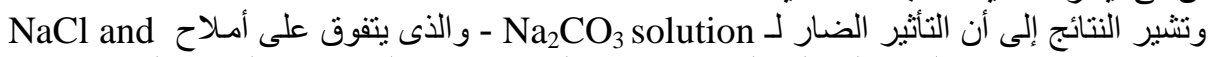

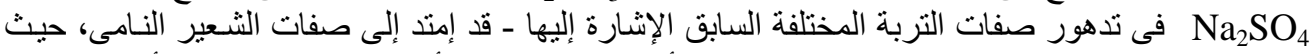

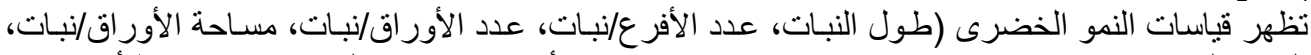

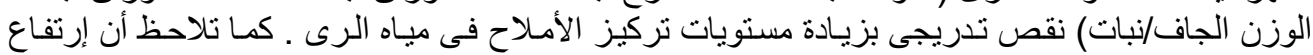

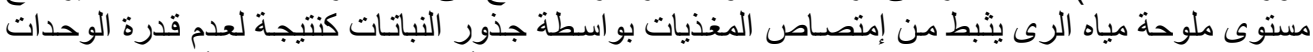

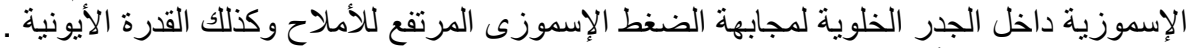

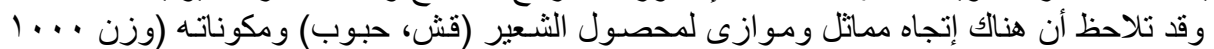

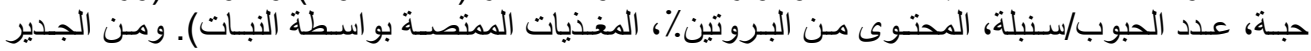

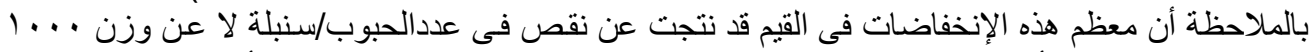

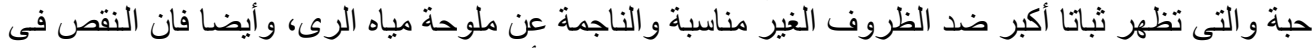

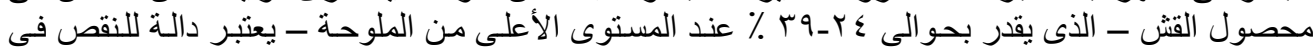
القدرة التفر عية ولحد ما فى طول النبات . ل

Fayoum J. Agric. Res. \& Dev., Vol.19, No.2, July, 2005 